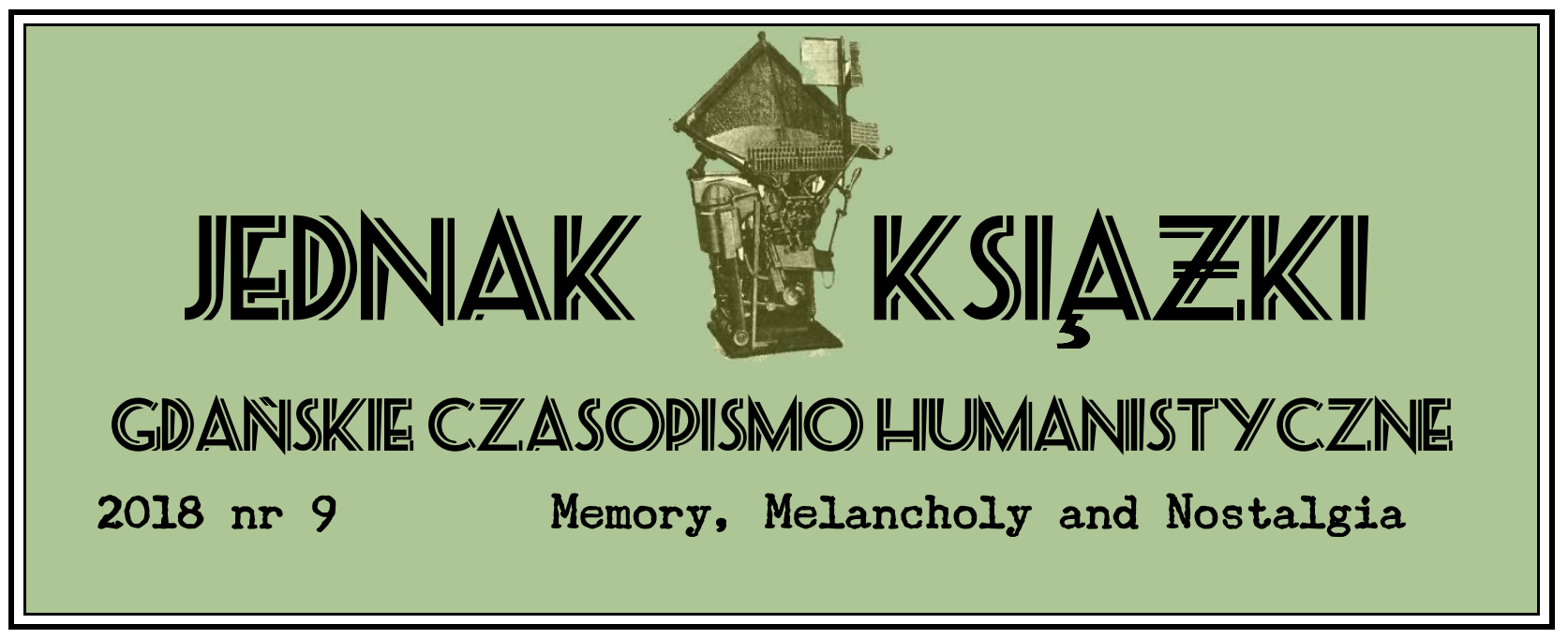

\title{
STUDIESS
}

\section{NOSTALGIA FOR THE LOST HOMELAND AS PART OF IDENTITY IN ALE் RŪTA'S WORKS}

INGRIDA EGLE் ŽINDŽIUVIENE்

Vytautas Magnus University (Lithuania)

Department of Foreign Language, Literary and Translation Studies

\section{Introduction}

lè Rūta (Elena Nakaité-Arbienè (1915-2011) is a famous Lithuanian diaspora writer,
the author of thirty novels and collections of essays and short stories. In her works,
she combined the traditional realistic story-telling techniques, ethnographic information, historical data, lyric and idealistic mode, and dramatic inner monologues. During her literary career she became one of the most prominent Lithuanian diaspora authors in the U.S.A. In Lithuania, she studied literature at Vytautas Magnus University before World War Two, and continued her studies at Vilnius University, from which she graduated in 1943. In 1944, with many other Lithuanians, she fled from the Soviet occupation, and spent four years in Germany. 
In 1948, she moved to the United States of America, where she lived in Santa Monica, California, until the last days of her life (Sužiedèlis and Jakštas 1975: 566). As Alè Rūta had once confessed, reading in German and French languages had a great influence on her own writing style (Egzodo rašytojai 1994: 654). She liked mentioning Gustave Flaubert, from which she obviously borrowed the realistic style. In most of her works she expressed love for her homeland and the Lithuanian countryside, and a wish to disclose and share the history of the country, especially focusing on the tragic periods. However, one specific issue remained the most important one in her works: she sensitively described the feeling of loneliness in a foreign land, disclosing the feelings of nostalgia for one's own country, its people, language, culture and traditions - feelings and emotions well-known to many immigrants. Alè Rūta had acknowledged many times that all her works were inspired by the feelings of nostalgia for her country, Lithuania. It would be difficult to find another Lithuanian author, who would have expressed such great suffering over the lost homeland and a deep sense of nostalgia for it. However, the author was sometimes criticized for a high degree of sentimentality, which most naturally had arisen from the nostalgic feelings, so typical of many people, who were forced to leave their country. Although her novels contain elements of historic or romance stories, the memories of her homeland are present in most of her works.

Moreover, Alè Rūta's novels present valuable information about the life of Lithuanian immigrants during different periods: for example, the first novel of the trilogy describes the life of the first waves of Lithuanian immigration in the U.S. Therefore, it is possible to state that the author records the national memory, especially that part which had been rather vague and full of gaps for many years. During the years of Soviet occupation of Lithuania (1944-1990) her works were not accessible to Lithuanian readers: all of them being published in the U.S.A., they were considered a "threat" to the Soviet political (and "moral"!) system. In addition, many of her works tell, in a way, a story of the road to the American Dream; however, based on the preservation of national values - an opposite to the so-called Soviet symbolism. Thus, only after 1990, when Lithuania finally regained its independence, her works became known to Lithuanian readers. In fact, with her novels, especially the ones, the theme of which is immigration, the author crosses literary boundaries of one country: the novels become extraordinary examples of cross-cultural issues, problems of adaptation, preservation of one's own national identity, or acquisition of another identity in a host country. Mainly, these issues make her works not only significant sources of historic information, but may also provide recent immigrants with sensitive insights into the ways of maintaining the bond with the homeland. Interestingly, the author's style and plot structure of the novels (at least the ones of the immigration topic) are like American 
bestsellers - urgent themes, intriguing actions, multiplicity of events, vividly created and easily recognizable characters and their lives, everyday family communication and adaptation to the norms of the host country. In the novels, which are the object of this article, two literary traditions, Lithuanian and American, seem to merge; therefore, the readers encounter American reality at different time periods, situation in the host country and relations in Lithuanian communities there, their effort in preserving national identity or regret over its decline or extinction. Thus, it is not surprising that Ale Rūta's novels were well-received by Lithuanian diaspora in the U.S. and Canada. Lithuanian immigrants found the description of the immigrants' lives and problems very similar to their own; they were able to recognize examples of their own stories of immigration and search for the American Dream, social and generational conflicts, nostalgia for the lost homeland and other problems, generally very well-known to immigrants. Mainly these issues also make Alè Rūta's works a part of multifold American literature.

\section{The Role of Nostalgia in Preservation of National Identity}

Nostalgia, a feeling of longing and affection for a period of the past, is also described as a special desire to and a process of return in thought to a former time/period/place in one's life, to one's home or homeland, or to one's family and friends, etc. Janelle L. Wilson rightly observes a certain degree of sadness implied in the word "nostalgia": "the fact that the individual is removed from that ideal situation can trigger sadness and a sense of loss" (Wilson 2005: 2). In general, nostalgia is often defined as a sentimental (!?) yearning for the happiness of a former place or time. Ale Rūta's trilogy on the life of Lithuanian immigrants seems to fall into the categories, outlined by Stuart Tannock, who identifies three key ideas: a prelapsian world of the past, a lapse (separation or fall), and a postlapsarian world (the present, which is lacking, deficient or oppressive) (Tannock in Wilson 2005: 4; my emphasis). Although Janelle L. Wilson agrees that "nostalgia is a form of ideologizing or mystifying the past," she determines the fact that "nostalgia serves the purpose of bonding" (Wilson 2005: xxi). The trilogy by Ale Rūta is based on the fundamental bonding of immigrants: in their memories of the past (which is always based on the memories of the homeland), they construct their new identity. Wilson agrees with Fred Davis (1979: 51) and defines such nostalgia "as facilitating the continuity of identity" (Wilson 2005: 13). Describing the life of the immigrants, Ale Rùta demonstrates that nostalgia for the homeland is a part of preservation of national identity. To use Wilson's term, "nostalgia that is linked to a group [...] is collective nostalgia" (Wilson 2005: 66). In fact, Alè Rūta's trilogy on the life of the immigrants 
("The Destiny of the Exiled") can be called the trilogy of collective nostalgia, because in these three novels (Pirmieji Svetur (1984; Eng. - The First Abroad), Daigynas (1987; Eng. - The Seedling Plot), and Skamba tolumoj (1997; Eng. Echoes from Afar)), the author describes different levels of nostalgia and its relationship to national identity.

Fred Davis determines "collective and private nostalgia" and states that collective nostalgia can "forge a national identity" (Davis 1979: 37; 51). Both forms, collective and private, exist in the texts by Ale Rùta: in the trilogy, collective nostalgia is embedded in the private one, and the private nostalgia is nourished by the collective one. Svetlana Boym outlines two other types of nostalgia: "restorative and reflective" and explains that "they are about the ways in which we make sense of our seemingly ineffable homesickness and how we view our relationship to a collective home" (Boym 2001: 41). Boym specifies these two types of nostalgia as follows: "Restorative nostalgia puts emphasis on nostos and proposes to rebuild the lost home and patch up the memory gaps. Reflective nostalgia dwells in algia, in longing and loss, the imperfect process of remembrance" (Boym 2001: 41; italic in the original). Boym rightly notices that "restorative nostalgia evokes national past and future; reflective nostalgia is more about individual and cultural memory" (Boym 2001: 49). These two types of nostalgia appear on different levels and scope and become intertwined throughout the text in Ale Rūta's trilogy; however, the third part contains a much stronger reflective nostalgia than the first two novels.

\section{Immigration of Lithuanians into the United States of America: A Short Overview and Its Representation in Alè Rūta's Trilogy}

Ale Rūta's trilogy “The Destiny of the Exiled” discloses the history of Lithuanian immigrants in the United States. Until the $20^{\text {th }}$ century, when quotas of immigration were issued for different countries, the record of Lithuanian immigrants, entering the U.S.A. is not exact, as Lithuania was annexed to the Czarist Russia at that time. Simas Sužiedelis observes that "isolated Lithuanians are known to have reached the shores of what is now the United States as early as the $17^{\text {th }}$ century. [...] However, not until the eighth decade of the $19^{\text {th }}$ century did Lithuanians begin settling in the United States massively." (Sužiedèlis 1972: 149).

Lithuanian researchers determine four major waves of Lithuanian immigration into the U.S.A. The first wave of immigration started after the rebellions of 1831 and of 1863-1864 against the Russian empire, when participants of the anti-Russian rebellion and their supporters flew from Lithuania. Thus, in the 19th century, occupation by Czarist Russia and persistent 
persecutions drove numerous Lithuanians to emigrate to the U.S. The first wave of immigration (300,000-600,000) continued until approximately the start of World War One, in 1914. The total number of immigrants entering the United States varies in different sources, as the exit country for some immigrants was considered Russia. The second wave of immigration $(100,000)$ happened in the period of 1920-1940, a period of independent Lithuania. At that time immigration quotas were established; thus, the record of immigrants from European countries (especially Eastern and Central Europe) became more exact. The third wave of Lithuanian immigration, the so-called "political immigration" happened in 1944, at the end of World War Two, when more than 60,000 of Lithuanians moved to Western Europe in fear of Soviet occupation and repressions. Many of these immigrants or their family members had experienced Soviet repressions of 1940-1941 or had participated in the resistance against the Soviet regime; thus, they were well-aware of the oncoming disaster in the country and, therefore, chose political exile. Immigrants of this third wave of immigration did not call themselves "immigrants", but "exiled" or "displaced persons."

The fourth wave consists of contemporary emigration from Lithuania into the U.S.A. The Lithuanian diaspora in the U.S. is one of the 36 Lithuanian diaspora groups across the world. Chicago, Illinois, is home to the second largest Lithuanian communities in the world. The coal region of northeastern Pennsylvania (the setting of the first part of Ale Rutta's trilogy) has the largest percentage of Lithuanian Americans in the United States.

The period of the first and second waves of immigration is portrayed in Ale Rūta's Pirmieji svetur (The First Abroad, 1984), in which the author scrupulously discloses different aspects of immigrants' life: first days in the unknown country, acquisition of the language, hard work at the coal mines, success and failure, publication of first English-Lithuanian dictionary (1875) or first Lithuanian newspaper in the U.S. (1879), family relationship, sense of community and many other issues. In the period of 1879-1914, 100 periodicals were published in the Lithuanian language across the United States - a fact, which is also observed in the first novel of the trilogy. It is important to notice that alongside discussion of the life of immigrants, in the trilogy the author discusses social and political events in the United States. She places the characters of the novels in different periods and, thus, describes the overall aspects of life in the host country. From this perspective, Ale Rūta's works contain an "informative approach", intermingled with the empathic one, grounded in the bonding sense of nostalgia (Vickroy 2002: 21).

In the first novel, The First Abroad, the main character, Kazys, an immigrant from Lithuania, views everything through comparison: "[the sun] is the same as in Klaipeda or their village" (Alè Rūta, Pirmieji svetur, The First Abroad, 1984: 51-52; here and further my translation 
from Lithuanian into English). He deeply longs for the homeland, waits for the letters from the family members, reads the Lithuanian newspaper (published in the U.S.) and later writes articles for the newspaper, becomes engaged in patriotic activities of the Lithuanian community, and fights for the preservation of the Lithuanian language in the Lithuanian communities and families. In his own family, he preserves love for the homeland and the language. Kazys likes talking about Lithuania with his family members, sharing the emotional feeling of nostalgia with them. His home contains national attributes: the family pursues Lithuanian traditions, family members use only the Lithuanian language at home; they celebrate Lithuanian holidays, sing Lithuanian songs, attend Lithuanian mass, support Lithuanian church and bury their countrymen in Lithuanian cemeteries. Unable to return to the homeland, they recreate or restore the homeland in their thoughts or immediate surroundings. A special "diasporic intimacy", to use Boym's (2001: 252) term is built, that nourishes restorative nostalgia, which "gravitates toward collective pictorial symbols and oral culture" (Boym 2001: 49). However, as Boym notices, "diasporic intimacy does not promise a comforting recovery of identity through shared nostalgia for the lost home and homeland" (Boym 2001: 254). Instead of recovery of identity it only helps to build and maintain the links to national identity.

In the second novel of the trilogy (Daigynas (The Seedling Plot)), the author discusses life of the second and third generation immigrants and describes people of the second and third waves of immigration into the U.S.A. Nostalgia, which was a natural, deeply nourished and bonding feeling, characteristic of the first generation, becomes an exotic feeling, but still a recognizable one: "[My father] would always tell a tale... About Lithuania, about his parents' garden, with white blossoms of cherry-trees and apple-trees; and where in summer busy bees were flying all around" (Ale Rūta, Daigynas, 1987: 539). In the second part of the trilogy, restorative nostalgia becomes quite minimal and is replaced by gradually weakening reflective nostalgia. Svetlana Boym explains that "if restorative nostalgia ends up reconstructing emblems and rituals of home and homeland to conquer and spatialize time, reflective nostalgia cherishes shattered fragments of memory and temporalizes space" (Boym 2001: 49). Those shattered fragments of memory become explicit in the second part of Ale Rūta's trilogy. It seems that the main character, a third-generation immigrant, contemplates these remaining pieces of memory, trying to reconstruct his parents' and grand-parents' link to the homeland. However, the author is quite pessimistic about recreating the bond from very small fragments and demonstrates that this link is too fragile to continue. In addition, the author discusses different levels of relationship between the earlier immigrants and later ones. These issues make the second novel a significant 
source of information on the mutual mis/understanding among different immigrant groups and generations.

The third part is structurally grounded in reflective nostalgia, which is the leading motif of the narrative. It is important to notice that in the Preface to the third novel (Ale Rūta, Skamba tolumoj; Eng. Echoes from Afar), the author admits of her own inability to adjust to American life style and expresses a wish to disclose the emotional changes in different generations and groups of immigrants. The author describes that the special "flow of nostalgia, so typical of the parents' or grand-parents' generation, like Ariadne's thread, is the only link that joins the immigrants to their roots, at least in their minds or hearts" (Alè Rūta, Skamba tolumoj, Echoes from Afar, 1997: 5). Therefore, the author explicitly points at the significance of nostalgia and its role in the life of immigrants. Different from the first two novels, the third part of the trilogy focuses on the new generation of immigrant families and describes their adaptation to the American lifestyle. The point of view of the second or third generation immigrants becomes different - to them, most probably, the homeland becomes the U.S., and the far-away country, Lithuania, is just something their parents keep remembering. The exoticism of this parental longing, which was so typical of immigrants in the second novel, now becomes even stronger. Moreover, the new generation becomes critical of their parents' nostalgic attachment to that "perfect country" where "everything was better and nicer" (Alè Rūta, Skamba tolumoj, Echoes from Afar, 1997: 19). The main character, a second-generation immigrant, Ginas, thinks that Lithuania is “a different world - his parents' past, their roots. Relatives, tribe, historical ancestors" (Alè Rūta, Skamba tolumoj, Echoes from Afar, 1997: 22; my emphasis). Although being able to visit Lithuania, the country remains foreign to him - something totally different and hardly understandable. A special narrative structure in the novel (two plot lines) helps the author focus on the nostalgic feelings for the homeland. The main character, Ginas, dates Asta (also a second-generation immigrant), who gives him her mother's old letters written to a friend in Lithuanian. As Ginas is better in understanding the written Lithuanian language, Asta wants him to retell and explain the texts of these letters to her. Mainly, through these letters the relationship between them becomes closer. In this way, the author creates an imaginative bond, built on nostalgic feelings, which brings these two people together and, therefore, creates the necessary bond between generations. In fact, this second plot line, consisting of old letters, discloses the author's nostalgic attitude towards her lost homeland: here the reader encounters nostalgic description of cozy country houses, the smell of the lime-trees, a walk through narrow roads in the moonlight at night, the glistering of dew drops at night, or the weeping sounds of harmonica afar" (Ale Rūta, Skamba tolumoj, Echoes from Afar, 1997: 95-96). Obviously, the author 
involves the reader in the reminiscences of her and their homeland and shares her wish to get closer to it, at least in thoughts. These reminiscences form a platform of reflective nostalgia, the essence of the narrative in the third novel.

Thus, those two plot lines become tightly intertwined, so that Ginas better understands his father, who is crying over the hardships destined for his homeland. In addition, the letters he reads to his girlfriend make him acknowledge and comprehend nostalgia prevailing at his parents' home. These old letters reveal to him a whole new world or a whole new attitude to the understanding of his own roots. The author describes different forms of nostalgia, singling out "black longing - comprehension that everything has been lost forever" (Alè Rūta, Skamba tolumoj, Echoes from Afar, 1997: 189). This "black longing" is echoed in the poems and songs inserted in the novel. For example, Ginas remembers a hymn heard at a Lithuanian church in Chicago during a national holiday: "God take care of our land, / our brothers there - working and creating, -/take care of Lithuania, where our national roots and soul remain. /In the way our minds always travel, / let our works and creation return there-/ to one nation, to that cherished land" (Alè Rūta, Skamba tolumoj, Echoes from Afar, 1997: 199). The romanticized and idealized description of the beauty of the lost homeland, the smells and sounds, the sights of the stars in the sky at night, words of Lithuanian songs continue until the end of the novel and create perception of collective nostalgia, and can be summarized, to quote Boym, as "poethics of reflective nostalgia", grounded in the poetic form of the nostalgic ethics (Boym 2001: 337; italic in the original).

Arthur G. Neal discusses the issue of "the collective sadness of a national trauma", which is permeated in the lives of the traumatized (Neal 2005: 5). Similarly, collective nostalgia, which follows the traumatic loss of the homeland, becomes a leading trait of the life of the immigrants in Alè Rūta's novels. Moreover, as Neal observes, "The traumas of the past become ingrained in collective memories and provide reference points to draw upon when need arises" (Neal 2005: 7). Nostalgia, as Wilson states, "requires a supply of memories"; memories become important aspects of posttraumatic period and the means of shaping nostalgia (Wilson 2005: 2). As if signaling the loss of national identity, Alè Rūta invites her readers (first, members of Lithuanian diaspora) to engage themselves in nostalgic reminiscences, pointing at the need and significance of such process. Wilson rightly notices that "expressing and experiencing nostalgia require active reconstruction of the past - active selection of what to remember and how to remember it" (Wilson 2005: 5). Therefore, it is possible to consider selective nostalgia as a most significant issue in the process of remembering the past. Christine R. Kovach observes that reminiscing "may help the person maintain his or her self-concept through the life span" (Kovach in Wilson 
2005: 128). Similarly, J. A. Meacham identifies three reasons why reminiscences are valued: they reflect the remembering of individual's membership in and identification with significant groups; they arouse similar feelings in others and incite them to cooperative action; the constructed meaning of memories can be validated through dialogue with others (Meacham in Wilson 2005: 128). Thus, in the third novel of the trilogy, those three aspects of reminiscences become significant, because through them a special nostalgic bonding is built and maintained. Contrary to Boym's (2001: 44) idea that "nostalgia is an ache of temporal distance and displacement", it is possible to view nostalgia in Alè Rūta's works as a cure and bonding.

To sum up, the trilogy is based on the great sense and different levels of nostalgia over the lost homeland. The author wants to share this loss with the readers and to remind them of things that should not be forgotten. In a way, she uses that thread (Ariadne's thread) of nostalgia to link different generations and to build a firm bond of collective memory. The traumatic experience of flight from the homeland, horrors of the past, emigration and settling in another country are grounded in nostalgic narrative tone of Ale Rūta's novels. Thus, nostalgia becomes a special bond which unites immigrants and generations. Wilson (2005: 66) rightly observes that nostalgia can be viewed "as means of recreating a sense of community"; therefore, nostalgia becomes one of the central issues in the life of immigrants. The trauma of losing one's own country is shifted onto next generations by means of nostalgic reminiscences. Nostalgia also helps to deal with this trauma of loss, so that these novels represent, to use Cathy Caruth's words, "the transformation of trauma into a narrative memory" (Caruth 1995: 153). In his book Writing History, Writing Trauma, Dominick LaCapra discusses the trauma of historical loss and absence, which becomes a "constitutive feature of existence" (LaCapra 2001: 65). The trauma of losing the homeland is present in Alè Rūta's works; however, this sort of nostalgia is a constituent part of immigrant identity and becomes an identity-forming trait recognized in different groups of immigrants. Such nostalgia is also a part of the "postmemory (the acquired memory of experiences one did not oneself live through)" (LaCapra 2004: 88). It is possible to view Ale Rūta's novels as testimonial narratives of traumatic nostalgia. Laurie Vickroy questions the role of transgenerational transfer: she analyses issues that are passed from one generation to another (Vickroy 2002: xiii). From this perspective, it can be stated that Ale Rūta passes on a great sense of nostalgia, which turns into a special code or a bond linking immigrants of different generations. Thus, the author uses the lost country as a framework and employs nostalgia in the structure of immigrant and national identity. 


\section{Conclusion}

All three novels in the trilogy by Ale Rūta provide the reader with valuable information about American society and immigration, and raise problems of assimilation or integration of immigrants and their adaptation to the societal norms of another country. The author describes spread of the cities, growth of industry, improvement of health care, functioning and organization of companies, the system of education, types of leisure activities, people's hobbies, family relationship and communication styles. The novels also tell the history of Lithuanian immigration in the U.S.: hard labor in Pennsylvanian coal mines, settling in big cities, organization and activities of Lithuanian communities, their events, different forms of maintaining links with their family members and friends back in the homeland, and ways of preservation of Lithuanian identity. Thus, the trilogy is significant from the sociological point of view: relationship within Lithuanian diaspora, sharing nostalgic emotions, rejecting nostalgia or representation of different forms of nostalgia. Therefore, it can be stated that nostalgia, in general, remains an issue which shapes the national identity in Lithuania. Moreover, it shapes the identity of Lithuanian immigrants in the U.S. The traumatic loss of a country (different forms of exile) has become embedded in the culture of the Lithuanian nation.

\section{ACKNOWLEDGEMENTS}

All articles published in the issue are the revised texts based on lectures delivered at the $4^{\text {th }}$ International Interdisciplinary Memory Conference in Gdansk "Memory, Melancholy and Nostalgia" (17-18 Semptember, 2015).

SUMMARY

\section{Nostalgia for the Lost Homeland as Part of Identity in Alè Rūta's Works}

The article examines the representation of nostalgic memory of the lost homeland, Lithuania, in the Lithuanian diaspora writer's, Ale Rūta's (1915-2011), trilogy called “The Destiny of the 
Exiled", which consists of the novels Pirmieji svetur (1984; Eng. - The First Abroad), Daigynas (1987; Eng. - The Seedling Plot), and Skamba tolumoj (1997; Eng. Echoes from Afar). These novels describe the multilayered problems of Lithuanian immigration into the U.S.A. and life of the immigrants there. Ale Rūta (Elena Nakaité-Arbienè) is a well-known Lithuanian author, most of whose works (novels and collections of short stories and poems, all written in the Lithuanian language) have been published by the publishers of Lithuanian diaspora in the United States of America. The trauma of the loss of the native land results in the transmitted nostalgia in her novels. The author both mourns over the lost homeland and shares with the readers her grief over this loss and longing for seeing it again. In doing this, Ale Rūta echoes the nostalgic voices of many immigrants, who left their native country at different periods. The article also discusses the issue of preservation of ethnic identity, which is constructed on nostalgic and often melancholic memories of the past, and explores different types of nostalgia, which forms a core of Ale Rūta's trilogy.

\section{KEYWORDS}

Immigration, traumatic experience, loss and longing, transmitted nostalgia

\section{BIBLIOGRAPHY}

Boym Svetlana. 2001. The Future of Nostalgia. New York: Basic Books.

Caruth, Cathy. 1995. Recapturing the Past: Introduction, 151-157. In: Caruth Cathy, ed. Trauma. Explorations in Memory. Baltimore: The Johns Hopkins University Press.

Davis Fred. 1974. Yearning for Yesterday: A Sociology of Nostalgia. New York: The Free Press.

Egzodo rašytojai. Autobiografijos. 1994. Vilnius: Lietuvos rašytojų sajungos leidykla.

Kovach Christine R. 1995. A Qualitative Look at Reminiscing: Using the Autobiographical Memory Coding Tool, 103-122. In: Haight Barbara K. and Webster Jeffrey D., eds. The Art and Science of Reminiscing: Theory, Research, Methods and Applications. Washington, D.C.: Taylor and Francis.

LaCapra Dominick. 2001. Writing History, Writing Trauma. Baltimore: Johns Hopkins University Press.

LaCapra Dominick. 2004. History in Transit: Experience, Identity, Critical Theory. Ithaca: Cornell University Press. 
Meacham J. A. 1995. Reminiscing as a Process of Social Construction, 37-43. In: Haight Barbara K. and Webster Jeffrey D., eds. The Art and Science of Reminiscing: Theory, Research, Methods and Applications. Washington, D.C.: Taylor and Francis.

Neal Arthur G. 2005. National trauma and Collective Memory. New York: M. E. Sharpe.

Rūta Alè. 1984. Pirmieji svetur. Chicago, Ill.: Draugas.

Rūta Alè. 1987. Daigynas. Chicago, Ill.: Draugas.

Rūta Alè. 1998. Skamba tolumoj. Išstumtuju dalia - 3. Klaipèda: AB "Klaipèdos rytas".

Sužiedèlis Simas and Jakštas Juozas, eds. 1975. Encyclopedia Lituanica, 566-567. Vol. 4. Boston: Encyclopedia Lituanica.

Sužiedèlis Simas, ed. 1972. Encyclopedia Lituanica, 149-152. Vol. 2. Boston: Encyclopedia Lituanica.

Tannock Stuart. 1995. "Nostalgia Critique.” Cultural Studies 9(3): 453-464.

Vickroy Laurie. 2002. Trauma and Survival in Contemporary Fiction. Charlottesville: University of Virginia Press.

Wilson Janelle L. 2005. Nostalgia. Sanctuary of Meaning. Lewisburg: Bucknell University Press. 